\title{
FATHOM
}

\section{Dans une prairie}

In a Eweleaze Near Weatherbury

\section{Thomas Hardy}

Traducteur : Françoise Baud et Eric Christen

\section{CpenEdition}

\section{Journals}

Édition électronique

URL : http://journals.openedition.org/fathom/606

DOI : $10.4000 /$ fathom.606

ISSN : 2270-6798

Éditeur

Association française sur les études sur Thomas Hardy

\section{Référence électronique}

Thomas Hardy, «Dans une prairie », FATHOM [En ligne], 3 | 2016, mis en ligne le 30 avril 2016, consulté le 01 mai 2019. URL : http://journals.openedition.org/fathom/606; DOI : 10.4000/fathom.606

Ce document a été généré automatiquement le 1 mai 2019. 


\title{
Dans une prairie
}

\author{
In a Eweleaze Near Weatherbury
}

\section{Thomas Hardy}

Traduction : Françoise Baud et Eric Christen

IN A EWELEAZE NEAR WEATHERBURY

The years have gathered grayly

Since I danced upon this leaze

With one who kindled gaily

Love's fitful ecstasies!

But despite the term as teacher,

I remain what I was then

In each essential feature

of the fantasies of men.

Yet I note the little chisel

of never-napping Time

Defacing wan and grizzel

The blazon of my prime.

When at night he thinks me sleeping

I feel him boring sly

Within my bones, and heaping

Quaintest pains for by-and-by.

Still, I'd go the world with Beauty,

I would laugh with her and sing,

I would shun divinest duty

To resume her worshipping,

But she'd scorn my brave endeavour

she would not balm the breeze

By murmuring 'Thine for ever!'

As she did upon this leaze.

DANS UNE PRAIRIE

Les années grises se sont accumulées

Depuis que je dansais dans cette prairie

Avec une jeune fille qui attisait gaiement

Les transports intermittents de l'amour!

Mes malgré les leçons du temps, 
Je reste celui que j'étais alors

En chaque trait essentiel

Des fantaisies des hommes.

Pourtant je remarque le petit burin

Du temps érodant sans relâche,

Dégradant le blason de ma jeunesse,

Le rendant blême et grisonnant.

Quand la nuit il me croit endormi,

Je le sens creuser sournoisement

Dans mes os, et accumuler

Les plus étranges douleurs pour bientôt.

Cependant je courrais bien le monde avec la Beauté,

Je rirais avec elle et je chanterais,

J'éviterais le devoir le plus divin

Pour reprendre mon adoration.

Mais elle mépriserait mes braves efforts,

Elle n'embaumerait pas la brise

En murmurant : « À toi pour toujours!"

Comme elle fit dans ce pré.

\section{BIBLIOGRAPHIE}

Thomas Hardy, Cent Poèmes. Choisis et traduits en français, ed. \& transl. Françoise Baud \& Eric Christen, Vevey: Les Éditions de l'Aire, 2008.

\section{RÉSUMÉS}

Poème daté de 1890, publié par Hardy dans son premier recueil, Wessex Poems (1898). La traduction française, reproduite ici avec l'aimable autorisation des traducteurs et de l'éditeur, est apparue pour la première fois dans l'ouvrage Cent Poèmes de Françoise Baud et Eric Christen ( L'Aire, 2008, p.56).

The poem, dated 1890, was originally published by Hardy in his first collection of verse, Wessex Poems (1898). The French translation was first published in Françoise Baud and Eric Christen's Cent Poèmes (L'Aire, 2008, p.56). It is reproduced here with the translators and publisher's kind permission.

\section{INDEX}

Mots-clés : poésie, traduction, français, amour, nostalgie, souvenir, vieillesse

Keywords : poetry, translation, French, love, nostalgia, memory, age 